and administrators of the law to do so in a way which supports technology and is generous to the inventor without harm to anyone else. Borderline cases will arise where the meaning of the terms 'plant' and 'animal' will have to be looked at closely but the constraints against patents for higher life forms are clearly built in to the present laws, at least according to the European model.

In presenting their survey of the patent law to the Supreme Court, the US judges of the lower court have approached the question on the pragmatic ground of usefulness to industry where they see no distinction between living microorganisms and chemical elements and compounds. If it is socially acceptable and desirable for pharmaceutical companies to develop new microorganisms and produce products containing living material such as "live" virus vaccines there can be no reason for restricting the patent cover available for these innovations.

To erect obstacles to patent protection is to encourage the secrecy which the patent law is designed to discourage. The patent system has in recent years become much more open especially with its emphasis on early compulsory publication of patent applications which in the past often remained confidential in the Patent Office for a long time. However, the emphasis on early publication has caused problems for microbiologists because a new strain of a microorganism must be available to third parties at the same time as publication. The European Patent Convention of 1973 set the trend on this point.

One of its regulations, Rule 28 , had said that a new strain must be deposited in a culture collection before a European patent application could be filed properly and also insisted on the accessibility of the strain to others, subject to a few conditions, on publication of the application 18 months or so after the priority date. This contrasted with US and Japanese patent law where release of the strain is obligatory only when an enforcible right is obtained.

However, the European Patent Office has recently modified Rule 28 . Availability of the strain to third parties can now be restricted between first publication of the application and the eventual grant of patent rights. During this time the applicant will be able to limit access to the strain to an independent expert acting on behalf of third parties but bound by certain conditions including that of not passing the strain out of his hands.

This improvement of the rule concludes over six years of effort by European industry and others to persuade the authorities that unrestricted availability of the culture before any rights are granted involves loss of control at too early a stage. This has been one of the first controversial questions tackled and solved by the EPO since it began operation in June 1978. The decision to change the rule has anticipated

\section{Evolving ideas}

EVOLUTION is not really in trouble, of course, it has never been healthier. It has gone into the computers. This is a sad business when one thinks of the halcyon days about a century ago. It is true that Darwin, the brooding sage, was a recluse at Down, but his supporters were having a wonderful time. We have been reminded of this in the splendid television series "The Voyage of the Beagle", and especially by the exciting re-enactment, on this programme, of the confrontation between Bishop Wilberforce and Thomas Huxley. The question asked by the Bishop was on which side Huxley claimed descent from the apes. Today we might reply that the maternal line of inheritance has a slight edge because mitochondria probably travel with ova. However, Huxley's thunderous response was directed personally at Wilberforce, whereupon it is said, a young woman fainted. Ironically, Queen Victoria, the supreme head of Wilberforce's church, carried a mutant gene for one of the blood-clotting globulins (Factor VIII), for the male haemophiliacs among her descendants provided a tragic and classic example of the ruthless effects of natural selection.

Evolution then set forth for many years on an adventure among fossils of extinct animals and plants. Pterodactyl, Tyrannosaurus and Archaeopteryx became household words. Descriptions of the bones of our ancestors were often in the news. The Scopes trial put evolution into the field of entertainment. Next, biochemists devised methods for determining the sequences of amino acids in proteins. It became possible to measure evolutionary divergence numerically in terms of amino acid differences between similar proteins in various species. Haemoglobins of gorillas, chimpanzees and human beings were distressingly similar, but widening differences were found in other species. The fun was disappearing from evolution, but worse was to come for the classical taxonomists. Incredibly rapid new methods were perfected for measuring long sequences of nucleotides in DNA, and the results, photoreduced to near-illegibility, appear in Nature almost every week.

A few years ago, we could examine

the UK report on biotechnology published last week (see Nature, 10 April, page 502) which strongly criticised the lack of protection under Rule 28.

Rule 28 was also updated to conform to the corresponding rule in the Budapest Convention of 1977 which provides that deposition of the strain in a single of ficially recognised culture collection will suffice for the individual, national procedures.

The detailed application of the independent expert idea remains to be

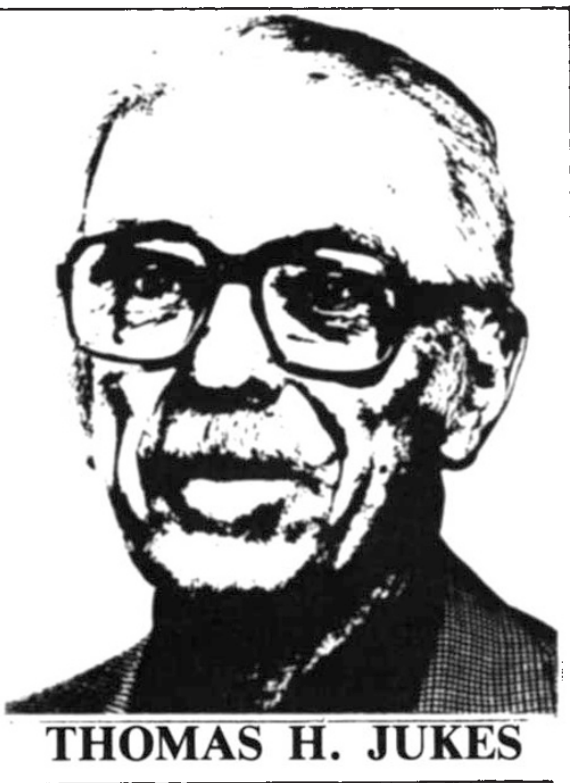

phenotypes but we never expected to be able to read genes. Now every sequencer can become a computer-aided evolutionist. Viruses evolve just like entire organisms; in fact, genes in simian virus 40 and the polyoma virus have diverged even further from each other than genes for the alpha and beta chains of haemoglobin, which have spread far apart in the 500 million years since they separated from a common ancestral molecule. But who knows how fast viruses evolve? They leave no fossilized imprints in the rocks as guideposts of their age.

To look for a gene in DNA, you scan for "open reading frames". These are regions in nucleotide sequences that are free from occurrences of TAA, TAG and TGA: the "stop signals" in protein synthesis. It is becoming quicker to find new proteins in DNA sequences than to separate them from protoplasm. It is even possible to find genes that are no longer in use. Phil Leder recently called such a gene (for a mouse alpha haemoglobin chain) a "rusting hulk", because it had accumulated so many changes, including deletions and insertions.

All evolutionary changes result from inherited changes in DNA molecules. It is difficult to get emotional about alterations in the linear arrangement of A, C, G and T. The spiritual descendanis of Bishop Wilberforce must find it rather dull to argue with computer programs.

worked out but the intention is that the expert will carry out experiments on behalf of third parties and potential opposers of the patent to test the patent disclosure and make an evaluation of the invention. The expert will be chosen by agreement between the applicant and the party requesting the strain or from an official list of recognised experts. Consequently the services of eminent microbiologists will be in demand and experts who might be willing to undertake this role are being canvassed. 